\title{
URGENSI PSIKOLOGI DALAM AKTIVITAS DAKWAH
}

\author{
Silvia Riskha Fabriar \\ Fakultas Dakwah dan Komunikasi \\ UIN Walisongo Semarang \\ Jln. Prof. Dr. Hamka, Ngaliyan, Semaran \\ silviariskhaf@walisongo.ac.id
}

\begin{abstract}
Da'wah is an Islamic communication, which is a communication activity carried out intentionally and consciously in the form of an invitation to the path of God with amar ma' ruf nahi munkar to achieve the happiness of humanity in the world and the hereafter. When preaching, the preacher needs to even have to know the psychological condition of the object being preached (mad'u) so that what is conveyed can later be conveyed properly. In this case, psychology provides a way to convey material and establish methods of preaching to humans who are totality (psychophysical) creatures and have personalities from both internal and external influences. Thus, psychology in the process of da' wah has a focal point in the knowledge of human behavior. Based on psychiatric or psychological elements, the process of preaching will proceed according to the needs that are expected of humans as individuals and social beings.
\end{abstract}

Keywords: da'wah, communication, psychology condition

\begin{abstract}
Abstrak
Dakwah merupakan suatu komunikasi Islam, yaitu suatu aktivitas komunikasi yang dilakukan secara sengaja dan sadar yang berupa ajakan kepada jalan Allah dengan amar ma'ruf nahi munkar untuk meraih kebahagiaan manusia dunia dan akhirat. Ketika berdakwah, da'i perlu bahkan harus mengetahui kondisi psikologis objek yang didakwahi (mad'u) agar apa yang disampaikan nantinya dapat tersampaikan dengan baik. Dalam hal ini, psikologi memberikan jalan bagaimana menyampaikan materi dan menetapkan metode dakwah kepada manusia yang merupakan makhluk totalitas (psikofisik) dan memiliki kepribadian baik dari faktor dalam maupun pengaruh dari luar. Dengan demikian, psikologi dalam proses dakwah mempunyai titik perhatian pada pengetahuan tentang tingkah laku manusia. Dengan berlandaskan unsur-unsur kejiwaan atau psikologi, proses dakwah akan berjalan sesuai kebutuhan yang diharapkan manusia sebagai individu dan makhluk sosial.
\end{abstract}

Kata kunci: dakwah, komunikasi, kondisi psikologis 


\section{A. Pendahuluan}

Islam adalah agama dakwah, agama yang menyebarluaskan kebenaran dan mengajak orang-orang yang belum mempercayainya untuk percaya, menumbuhkan pengertian dan kesadaran agar umat Islam mampu menjalani hidup sesuai dengan perintah dianggap sebagai tugas suci yang merupakan tugas setiap muslim. Dengan demikian, setiap muslim berkewajiban untuk berdakwah.

Dalam melaksanakan tugas dakwah, seorang da'i dihadapkan pada kenyataan bahwa individu-individu yang akan didakwahi memiliki keberagaman dalam berbagai hal, seperti pikiran-pikiran, pengalaman, kepribadian, dan lain-lain. Oleh karena itu, untuk mengefektifkan usaha dakwah seorang da'i dituntut untuk memahami mad'u yang akan dihadapi. Salah satu bentuk keberhasilan dalam dakwah adalah berubahnya sikap kejiwaan seseorang. Dari tidak cinta Islam menjadi cinta, dari tidak mau beramal saleh menjadi giat melakukannya, dari cinta kemaksiatan menjadi benci dan tertanam dalam jiwanya rasa senang terhadap kebenaran ajaran Islam.

Dakwah bermaksud mengubah sikap seorang mad'u, maka pendekatan psikologis menjadi sesuatu yang sangat penting. Dalam masyarakat modern, kedudukan dan peran psikologi dapat dikatakan sebagai sarana efektif berhasil tidaknya tujuan yang diharapkan, baik secara individu maupun secara kelompok. Di samping itu, psikologi memberikan pula cara-cara bagaimana yang lebih tepat dalam pemecahan masalah-masalah kemanusiaan, baik ia sebagai individu atau sebagai kelompok masyarakat, begitu pula dapat diterapkan dalam masalah agama, khususnya sebagai acuan metodologi dakwah, merupakan suatu yang tidak dapat ditinggalkan (M. Arifin, 1997: 10-12). Dari segi psikologi, dakwah dalam prosesnya dipandang sebagai pembawa perubahan. Dari segi dakwah, psikologi banyak memberi jalan pada perumusan tujuan dakwah pemilihan materi dan penetapan metodenya. Bagi seorang da'i mempelajari metode psikologi dapat memungkinkan mengenal berbagai aspek atau prinsip yang dapat menolongnya menelaah tingkah laku manusia dengan lebih kritis dan juga dapat memberikan pengertian yang lebih mendalam tentang tingkah laku.

Namun, dalam kondisi saat ini banyak da'i yang masih asal-asalan menjalankan dakwahnya tanpa memperhatikan bagaimana keadaan mad'unya. Da'i seringkali menyamaratakan setiap mad'u yang dihadapi, baik dari materi yang disampaikan dan metode yang digunakan. Sehingga mengakibatkan materi yang disampaikan tidak mengena bahkan dianggap sebagai angin lalu.

Dengan demikian, yang perlu diperhatikan oleh da'i adalah situasi dan kondisi masyarakat obyek khususnya situasi psikologisnya, dimana manusia sebagai makhluk yang mempunyai jasmani dan rohani yang unik. Proses perubahan dan perkembangan pribadi sasaran ( $\left.\operatorname{mad}^{\prime} u\right)$ dakwah sangat rumit. Da'i yang menghadapinya juga komplek sehingga memahami kondisi psikologi sangat dibutuhkan dalam proses ini. 


\section{B. Hasil dan Pembahasan}

\section{Pemahaman Mengenai Aktivitas Dakwah dan Psikologi}

Dakwah secara etimologis berasal dari bahasa Arab, kata dakwah merupakan masdar (kata benda) dari kata kerja da' a yad' $u$ yang berarti panggilan, seruan atau ajakan. Dan secara istilah Syekh Ali Mahfudh dalam Moh. Ali Aziz (2004: 4) mengatakan dakwah adalah mendorong manusia untuk berbuat kebajikan dan mengikuti petunjuk (agama) menyeru mereka pada kebaikan dan mencegah mereka dari perbuatan munkar agar memperoleh kebahagian dunia akhirat.

Dakwah merupakan usaha mewujudkan masyarakat yang menjunjung tinggi kehidupan beragama dengan merealisasikan ajaran Islam secara penuh dan menyeluruh. Menurut al Sayyid Sabiq, dakwah Islam memberikan perhatian terhadap manusia sebagai individu dalam tiga hal, jasmani, akal, dan moral. Perhatian terhadap jasmani mencakup penjagaan terhadap kesehatan jasmani, sehingga akan mampu menghadapi berbagai macam kesulitan.Sedangkanyang berkaitan dengan akal, Islam mengajak agar setiap individu dapat berpikir sehat dan jernih sehingga dapat mengambil keputusan berdasarkan kejujuran, keadilan, dan mampu untuk memahami lingkungan yang mengelilingi dan dapat belajar dari perjalanan umatumat yang terdahulu. Sedangkan moral berkaitan dengan ajakan untuk melatih hati agar mempunyai kecenderungan akan kebaikan dan menjauhi keburukan (Faizah dan Lalu Muhsin Effendi, 2006: 85-86).

Kegiatan dakwah merupakan suatu sistem (Habib, 1982: 154), karena dalam kegiatan dakwah melibatkan beberapa unsur, baik sebagai unsur utama maupun sebagai unsur pelengkap. Unsur-unsur itu terdiri dari da'i (subjek dakwah), mad'u (objek dakwah), materi, metode, media dan tujuan. Selain itu sering juga sebagian para ahli memasukkan perencanaan dan evaluasi sebagai unsur dakwah. Dakwah sebagai suatu sistem, selalu terdapat input, output, dan proses. Ketiganya harus selalu terkait dan sambung menyambung terus menerus sehingga merupakan suatu proses yang tidak berhenti pada satu titik (Aziz, 2004: 73) dan saling mempengaruhi dalam pencapaian tujuan.

Secara lebih operasional, dakwah adalah mengajak manusia kepada tujuan yang definitif yang rumusannya dapat diambil dari Al Qur'an maupun Hadits sesuai dengan lingkup dakwahnya. Sebagai peristiwa komunikasi, aktivitas dakwah dapat menimbulkan berbagai peristiwa ditengah masyarakat, peristiwa yang harmoni, menegangkan, kontroversial, bisa juga melahirkan berbagai pemikiran, baik pemikiran yang moderat ataupun ekstrem, sederhana maupun rumit, parsial maupun komprehensif. Oleh karena itu, da'i sebagai penyampai dakwah tidak hanya menguasai materi dakwah, tetapi juga memahami karakteristik manusia yang menjadi mad'u.

Dalam upaya mencapai tujuan dakwah maka kegiatan dakwah selalu diarahkan untuk mempengaruhi tiga aspek perubahan dari objeknya, yakni perubahan pada aspek pengetahuan (knowledge), aspek sikap (attitude), dan aspek perilaku (behavioral). Berkenaan dengan ketiga hal tersebut Jalaluddin Rakhmat dalam Moh. Ali Aziz (2004: 139) menyatakan:

Jurnal An-Nida, Vol. 11, No. 2, Juli-Desember 2019 
a. Efek kognitif terjadi bila ada perubahan pada apa yang diketahui, dipahami, atau persepsi khalayak. Efek ini berkaitan dengan transmisi pengetahuan, ketrampilan, kepercayaan, dan informasi.

b. Efek afektif timbul bila ada perubahan pada apa yang dirasakan, disenangi atau dibenci khalayak, yang meliputi segala yang berhubungan dengan emosi, sikap, serta nilai.

c. Efek behavioral, merujuk pada perilaku nyata yang dapat diamati, yang meliputi pola-pola tindakan, kegiatan atau kebiasaan berperilaku.

Dalam prosesnya, dakwah tidak bisa terlepas dari kondisi psikologi, sebab dengan memahami kondisi psikologis pelaku dakwah dapat mengerti karakter dan tingkah laku baik para da'i maupun sasarannya atau mad'u.

Psikologi menurut bahasa berasal dari kata Yunani, yang terdiri dari dua kata, psyche (jiwa) dan logos (ilmu). Jadi, psikologi adalah ilmu pengetahuan tentang tingkah laku dan kehidupan psikis (kejiwaan) manusia. Namun, pengertian ilmu jiwa itu sendiri masih dianggap kabur dan belum jelas. Menurut Sarlito Wirawan tidak seorang pun yang tahu apa sesungguhnya yang dimaksud dengan jiwa itu sendiri, karena jiwa adalah suatu kekuatan yang abstrak yang tidak tampak oleh panca indera wujud dan zatnya, melainkan yang tampak hanya gejala-gejalanya (Sarwono, 2000: 3).

Robert S. Woodworth dalam Kartini Kartono (1996: 1-2) berpendapat bahwa psikologi adalah ilmu pengetahuan yang mempelajari semua tingkah laku dan perbuatan individu, dimana individu tersebut dapat dilepaskan dari lingkungannya. Pelaksanaan secara ilmiah dari psikologi dilakukan dengan jalan mengumpulkan dan mencatat secara teliti tingkah laku manusia selengkap mungkin dan berusaha menjauhkan diri dari segala prasangka.

Dalam pandangan psikologi, George A. Miller menyatakan bahwa psikologi mempunyai objek pembahasan yang berupa mental atau jiwa manusia secara luas. Pembahasannya bersifat ilmiah yang didukung oleh hasil penelitian yang dilakukan oleh metode ilmiah pula. Hal ini berbeda dengan William james yang membatasi objek pembahasan psikologi pada jiwa sadar manusia sehat, terdidik dan sebagainya. Yang djadikan objek penelitiannya adalah tingkah laku yang berhubungan dengan proses penyesuaian diri. Tingkah laku tersebut bertujuan untuk memenuhi tuntutan kebutuhan hidup biologis sebagai makhluk individual dan tuntutan hidup sosial sebagai makhluk sosial (Enjang dan Aliyudin, 2009: 28-29).

\section{Interaksi Psikologis antara Da'i dan Mad'u}

Manusia secara hakiki merupakan makhluk sosial, sejak ia dilahirkan ia membutuhkan orang lain untuk memenuhi segala kebutuhannya. Manusia menjadi apa dan siapa tergantung dengan siapa ia bermasyarakat. Manusia disatu sisi memiliki sifat kooperatif, tabiat bekerja sama dengan manusia lain dalam memenuhi kebutuhan. Jadi, dalam kehidupannya, individu selalu berhubungan dengan lingkungan fisik, lingkungan psikis, atau lingkungan rohaninya. Salah satu bentuk hubungan 
manusia dengan lingkungannya adalah interaksi sosial.

Interaksi sosial berkisar pada usaha menyesuaikan diri baik bersikap autoplastis (mengubah diri sesuai dengan lingkungannya) maupun alloplastis (usaha seseorang untuk merubah lingkungannya) sesuai keadaan (keinginan), dimana individu yang satu menyesuaikan diri dengan individu yang lain. Faktor-faktor adanya interaksi sosial adalah:

1. Imitasi, yaitu tindakan seseorang untuk meniru orang lain baik sikap, penampilan, maupun gaya hidup.

2. Identifikasi, yaitu kecenderungan atau keinginan dalam diri seseorang untuk menjadi sama dengan pihak lain.

3. Sugesti, yaitu proses dimana seorang individu dapat menerima suatu penglihatan atau pedoman-pedoman tingkah laku dari orang lain tanpa kritik terlebih dahulu.

4. Simpati, yaitu proses kejiwaan seseorang yang merasa tertarik kepada seseorang atau kelompok karena sikap, penampilan, wibawa atau perbuatan.

Dalam setiap proses dakwah pasti terjadi proses interaksi, yaitu interaksi antara da'i dan mad'u. Dalam proses dakwah interaksi digunakan untuk mempengaruhi mad'u dengan harapan adanya perubahan sikap, pengetahuan, dan tingkah laku sesuai dengan materi dakwah yang disampaikan, yaitu demi mencapai kebahagiaan dunia dan akhirat.

Dalam proses dakwah, da'i harus benar-benar mengerti kondisi mad'u baik dari segi umur, pengetahuan, pendidikan, geografis, dan lain-lain. Faktor-faktor dasar interaksi seperti sugesti, imitasi, simpati mengharuskan da'i mempunyai ciri-ciri dan kepribadian yang prima untuk dapat menarik mad'u (Mubarok, 1999: 98). Selain itu, da'i harus dapat membina hubungan yang baik dengan mad'u, sehingga mad'u tidak ragu untuk mencontoh dan meneladani sikap dan pribadi mad'u. Proses saling mempengaruhi antara da'i dan mad'u ini merupakan peristiwa mental.

Dalam proses dakwah, arti interaksi sosial antara da'i dan mad'u sekurangkurangnya terkandung tiga makna, yaitu:

a. Da'i maupun mad'u sebenarnya terlibat dalam proses belajar, baik dari segi berpikir maupun dari sudut merasa. Mad'u belajar kepada da'i, tetapi da'i juga belajar kepada umpan balik yang disampaikan oleh mad'u.

b. Antara da'i dan mad'u terjadi proses penyampaian dan penerimaan lambanglambang dalam berkomunikasi (tepuk tangan lambang suka, gaduh dan mengantuk lambang penolakan).

c. Adanya mekanisme penyesuaian diri antara da'i dan mad'u.

Interaksi memiliki hubungan yang erat kaitannya dengan proses komunikasi, yaitu ketika mad'u menerima informasi, mengolahnya, dan menyimpannya yang akhirnya menghasilkan efek perubahan sikap. Menurut Djamaludin Ancok dan Fuat Nashori Suroso (1994: 39) proses perubahan sikap seorang mad'u yang dari tidak tahu atau tidak menerima pesan ke menerima tersebut dapat terbentuk sangat tergantung pada ketiga aspek komunikasi, yaitu komunikator, komunikasi, dan audience.

\section{Peran Psikologi dalam Proses Dakwah}

Dakwah Islam merupakan proses penyampaian ajaran Islam terhadap umat 
manusia.Sebagaisuatu proses, dakwahtidak hanya merupakan usaha penyampaian, tetapi merupakan usaha mengubah way of thinking, way of feeling, way of life menusia sebagai sasaran dakwah ke arah kualitas kehidupan yang lebih baik (Samsul Munir Amin, 2008: 29). Dalam aktivitas dakwah, seorang da'i seringkali mengalami kesulitan untuk menggerakkan sasaran dakwahnya agar mau mendengarkan dan mengamalkan pesan yang disampaikan dalam kehidupan nyata. Seorang da'i dihadapkan pada kenyataan bahwa individu-individu yang akan didakwahi memiliki keragaman dalam berbagai hal. Keragaman tersebut akan memberikan corak yang berbeda pula dalam menerima dakwah (materi dakwah) yang menyikapinya. Oleh karena itu, dakwah yang dilakukan harus berorientasi kepada kebutuhan sasaran dakwah dan da'i berusaha memotivasi sasarannya untuk mengamalkan pesan yang telah disampaikan.(Nawawi, 2007: 235). Dengan kata lain seorang da'i dituntut menguasai tentang kejiwaan manusia sebagai individu maupun anggota kelompok. Esensi dakwah sebenarnya terletak pada usaha pencegahan dari penyakit-penyakit masyarakat yang bersifat psikis dengan cara mengajak, memotivasi,merangsang serta membimbing individu agar sehat dan sejahtera jiwa dan raganya, sehingga mereka dapat menerima ajaran agama dengan penuh kesadaran dan dapat menjalankan ajaran agama sesuai dengan tuntutan syariat agama.

Pesan dakwah harus disampaikan dengan pendekatan psikologis, yakni sesuai dengan cara berpikir dan merasa mad'u. Dengan memperhatikan faktorfaktor perkembangan psikologis beserta ciri-cirinya, maka pesan dakwah yang disampaikan oleh da'i akan dapat meresap dan diterima dalam pribadi sasarannya kemudian diamalkan dengan perasaan yang tulus tanpa adanya ganjalan karena hal tersebut dapat menyentuh dan memuaskan kehidupan rohaninya. Dakwah seperti itu disebut dakwah persuasif.

Dakwah persuasif menurut Samsul Munir Amin (2009: 210) memerlukan persiapan yang sungguh-sungguh, sebab persuasi mendasarkan usahanya pada segi-segi psikologis dan tujuannya untuk meraih kesadaran seseorang untuk melaksanakan sesuatu. Persuasif adalah kegiatan psikologis, tujuannya untuk dapat mengubah sikap, pendapat, atau tingkah laku tanpa menggunakan ancaman, kekerasan, kekuatan, kekuasaan, penekanan, pemerasan tetapi dengan kesadaran, simpati, dan sepenuh perasaan.

Disinilah letak titik berat strategistrategi dakwah yang sebenarnya yaitu menerima pesan dakwah dengan ikhlas sekaligus mempraktekkannya. Akan tetapi, realitas psikologis menunjukkan bahwa materi pesan yang disampaikan da'i tidak secara otomatis diserap oleh mad'u. Pertimbangan - pertimbangan sasaran dakwah dalam menerima kehadiran sumber informasi menjadi kunci terhadap pertimbangan penerimaan dan pengambilan sikap terhadap materi dakwah (Musthofa, 2005: 103).

Dalam banyak hal, Nabi Muhammad sebagai juru dakwah juga memperhatikan kejiwaan umatnya. Sebagaimana Al Qur'an, dalam menerapkan hukum dan ajarannya tidak dengan serta merta mengabaikan unsur-unsur kejiwaan manusia. Turunnya ayat Al Qur'an secara bertahap merupakan 
suatu bukti bahwa pendekatan kejiwaan merupakan sesuatu yang tidak boleh diabaikan. Sebagai contoh adalah perintah tentang pelarangan minuman keras (khamar) bagi para pemeluk agama Islam. Allah membuat tiga tahapan:

a. Peringatan tentang mudharatnya, dalam QS. Al Baqarah: 219, yang artinya "Mereka bertanya kepadamu tentang khamar dan judi. Katakanlah: "Pada keduanya terdapat dosa yang besar dan beberapa manfaat bagi manusia, tetapi dosa keduanya lebih besar dari manfaatnya....." Selanjutnya mereka masih juga banyak yang minum khamar (minuman keras), sampai pada suatu hari, seorang dari Kaum Muhajirin mengimami sahabatsahabatnya pada shalat Maghrib. Bacaannya campur aduk antara satu dengan yang lain, sehingga Allah menurunkan ayat Al Qur'an yang lebih keras dari ayat sebelumnya:

b. Pelarangan sholat dalam keadaan mabuk, QS. An Nisa': 43, yang artinya "Hai orang-orang yang beriman, janganlah kamu shalat, sedang kamu dalam keadaan mabuk, sehingga kamu mengerti apa yang kamu ucapkan...". Akan tetapi, orang-orang masih juga banyak yang meminum minuman keras, hingga salah seorang melakukan salat dalam keadaan mabuk. Kemudian turunlah ayat Al Qur'an yang lebih keras lagi:

c. Perintah menjauhi khamar dalam QS. Al Mai'dah: 90, yang artinya "Hai orang-orang yang beriman, Sesungguhnya (meminum) khamar, berjudi, (berkorban untuk) berhala, mengundi nasib dengan panah adalah Termasuk perbuatan syaitan. Maka jauhilah perbuatan-perbuatan itu agar kamu mendapat keberuntungan." Jelas bahwa ajaran Islam dalam penerapannya juga memperhatikan masalah kejiwaan seseorang. Maka, tatkala seorang da'i akan melakukan aktivitas dakwahnya harus memperhatikan situasi dan kondisi psikologis orang yang akan menerima pesan-pesan dakwahnya.

\section{Teori Perubahan Sikap dalam Proses Dakwah}

Dalam proses dakwah, pesan dakwah harus disampaikan dengan hikmah, pelajaran yang baik (mauidhoh hasanah), dan bantahan yang baik (jidal bi ahsan) sebagaimana diungkap Al Qur'an dalam surat An Nahl ayat 125, yang artinya

"Serulah (manusia) kepada jalan Tuhanmu dengan hikmah dan pelajaran yang baik dan bantahlah mereka dengan cara yang baik. Sesungguhnya Tuhanmu Dialah yang lebih mengetahui tentang siapa yang tersesat dari jalan-Nya dan Dialah yang lebih mengetahui orang-orang yang mendapat petunjuk"

Al Qur'an memberikan landasan teoritis agar dakwah dilakukan dengan hikmah. Hikmah dalam bahasa sehari hari sering diartikan sebagai tindakan yang bijaksana. Orang yang bijak tentunya orang yang memiliki ilmu pengetahuan yang dalam, yang tidak hanya satu bidang tetapi juga pada bidang yang lainnya. Dengan pengetahuan yang dimiliki itu ia akan bisa memilih metode dan materi apa yang tepat untuk diberikan kepada sasaran dakwah yang dihadapi. Dengan demikian, aktivitas dakwah yang dilakukan akan mendapat respon positif dari mad'u yang pada akhirnya akan memudahkan da'i 
mendapatan keberhasilan dalam tugas dakwahnya. Dengan memahami segala sesuatu dalam arti segala unsur unsur yang berhimpun dalam kegiatan dakwah, yaitu unsur pesan dakwah, unsur manusia yang dihadapi, unsur medan dakwah, ruang dan waktu, unsur metode yang sesuai, sehingga daya penggerak untuk suatu langkah yang tepat, dengan itulah seorang dai dapat menentukan dan menjalankan dakwah yang efektif.

Jika ditinjau dari Psikologi Komunikasi, ada tiga faktor yang sangat menentukan keberhasilan dakwah, yaitu:

1. Siapa yang menyampaikan dakwah (komunikator).

2. Teknik Penyampaian dakwah (kominikasi).

3. Siapa penerima pesan dakwah (komunikan/audience).

Untuk menentukan keberhasilan dalam perubahan sikap sangat tergantung ketiga hal diatas. Dan mengenai perubahan sikap, dalam tulisan ini digunakan teori perubahan sikap yang dibahas McGuire. Menurut McGuire, proses perubahan sikap seseorang dari tidak tahu atau tidak menerima suatu pesan berlangsung melalui tiga proses dasar yang disebutnya tiga tahap perubahan sikap (Djamaludin Ancok dan Fuat Nashori Suroso, 1994: 40).

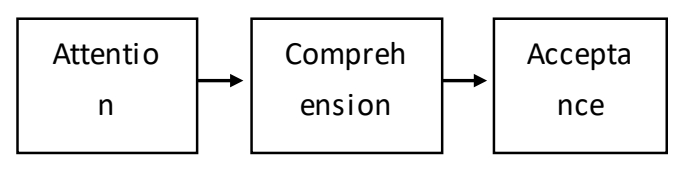

Attention adalah perhatian terhadap pesan. Orang tidak akan berubah sikap apabila tidak memperhatikan pesan yang disampaikan. Oleh karena itu, agar penyampaian dakwah dapat diterima harus ada usaha untuk menarik orang untuk memperhatikan dakwah yang disampaikan.

Comprehension yaitu pemahaman seseorang terhadap pesan. Seseorang yang memperhatikan pesan dakwah diharapkan mempunyai pemahaman terhadap pesan yangdisampaikanda'i. Adanya pemahaman terhadap pesan tersebut sangat ditentukan oleh bermacam-macam hal, diantaranya teknik penyampaian pesan dakwah dan bahasa yang dipakai dalam dakwah. Tanpa adanya perhatian terhadap pesan dakwah orang tidak mungkin akan memahami isi dakwah.

Acceptance adalah penerimaan isi dakwah. Dalam hal ini, ditolak atau diterimanya isi dakwah sebagai sikap hidup sangat ditentukan oleh pemahaman terhadap pesan dakwah dan juga sejauhmana pesan dakwah sesuai dengan kebutuhan dan nilai hidup pendengar. Dengan adanya penerimaan pesan dakwah ini diharapkan orang akan menjalankan perintah-perintah Islam yang disampaikan.

Dalam melakukan komunikasi (dakwah) persuasif, ketiga faktor tersebut merupakan rangkaian, yang baik secara langsung (penerimaan terhadap objek sikap) maupun tidak langsung berpengaruh terhadap perhatian individu pada isi pesan atau informasi mengenai objek sikap dan pemahaman terhadap informasi mengenai objek sikap. Dengan demikian, dalam mempengaruhi orang lain, seorang komunikator harus memfokuskan perhatian mereka menjadi bagian yang sangat penting agar isi pesan dapat dipahami oleh pendengar, kemudian menyetujui kesimpulan pesan yang disampaikan. Untuk mencapai tujuan ini, komunikator haruslah 
seorang yang mampu membuat individu tertarik, dan secara sukarela meluangkan perhatiannya untuk memahami isi pesan.

Berkaitan dengan proses kognitif yang terlibat dalam pembentukan dan perubahan sikap, McGuire juga mengemukakan konsep information-processing paradigm (teori pemrosesan informasi) bahwa sikap dapat terbentuk melalui 6 langkah, yaitu objek sikap (pesan) harus disajikan (a. Presentation) terlebih dahulu kepada individu. Apabila presentasi dilakukan dengan tepat dan menarik maka individu akan tertarik (b. Attention) terhadap objek sikap. Pesan yang disajikan dengan baik, menyebabkan individu bersedia secara sukarela mencurahkan perhatiannya, sehingga pemahaman (c. Comprehension) terhadap isi pesan akan lebih mudah dilakukan. Apabila isi pesan terkait objek sikap tersebut dipahami, tidak ada alasan bagi individu untuk menolak (d. Yielding). Pada saat ini benih sikap potensial terbentuk pada individu. Satu proses lagi yang dibutuhkan yaitu memperkuat dan memelihara agar pemahaman itu bertahan (e. Retention) sebelum akhirnya terwujud dalam perilaku (f. Behavior) yang dinginkan. (Ramadhani, 2009: 6; Aziz, 2009: 460).

Menurut McGuire selalu ada variabel lain yang ikut mempengaruhi tahap-tahap tersebut diatas. Misalnya, kecerdasan, bisa mempengaruhi seseorang untuk mudah menerima argumentasi orang lain. McGuire juga menyatakan bahwa perubahan sikap bukan hal persoalan yang sederhana, tetapi melibatkan semua komponen. Jika aktivitas dakwah hanya sampai membuat mad'u sampai pada tahap kognitif, bukan berarti dakwahnya gagal. Ia hanya berhasil sampai ke tingkat tersebut. Jika dakwah mengantarkan mad'u sampai pada tahap terakhir, maka itulah keberhasilan dakwah yang total. Akan tetapi, untuk sampai ke tahap terakhir sangat banyak variabel yang menyertainya.

Aktivitas dakwahyang berperan dalam masalah pembentukan perilaku ini adalah berupa pembinaan, bimbingan, danaktivitas pendidikan. Proses pembentukan dalam dakwah merupakan upaya transformasi ajaran Islam ke dalam psikologis seorang individu. Upaya transformasi ini dilakukan dengan komunikasi dan pembinaan, yang dipengaruhi oleh kondisi da'i, lingkungan, sasaran dakwah, dan hubungan nilainilai antar mereka. Oleh sebab itu, dengan memperhatikan psikologis mad'u dan kebutuhan hidupnya, maka pesan dakwah yang disampaikan oleh da'i akan dapat diterima dengan mudah dan akan diamalkan oleh mad'u karena hal tersebut menyentuh dan memuaskan kehidupan rohaninya. Dakwah yang terarah adalah memberikan bimbingan kepada umat Islam untuk benar-benar mencapai dan melaksanakan keseimbangan hidup di dunia dan akhirat.

\section{Simpulan}

Esensi dakwah terletak pada ajakan, dorongan, rangsangan serta bimbingan terhadap orang lain untuk menerima ajaran agama dengan penuh kesadaran. Seorang da'i harus mampu merangsang motif yang dimiliki mad'u sehingga mad'u mau bertingkah laku sebagaimana yang dikehendakioleh da'i. Dariruang psikologis, seorang da'i dapat menanamkan nilai-nilai ajaran dengan mengalirkan pesan-pesan sesuai kapasitas para jamaahnya. Pesan- 
pesan tersebut harus diramu sesuai selera budaya masyarakat.

Perubahan sikap dan tingkah laku merupakan tujuan utama yang diinginkan para da'i dan seringkali dijadikan tolok ukur keberhasilan dakwahnya. Sebagaimana tujuan utama dari dakwah adalah bagaimana nantinya seorang mad'u dapat atau mau menjalankan apa yang disampaikan oleh seorang da'i, bukan hanya sekedar dipahami, direnungkan dan dirasakan saja, serta bagaimana agar seorang mad'u benar-benar menjalankan apa yang disampaikan oleh da'i dengan penuh kesadaran dari dirinya sendiri.

\section{Implikasi Dan Keterbatasan Penelitian}

Da'i harus memperhatikan kondisi psikologis mad'u dalam setiap dakwahnya. Salah satu cara memperhatikan kondisi mad'u dengan menerapkan teori perubahan sikap dalam berdakwah, agar dakwah dapat berjalan efektif dan berhasil. Kajian ini dapat digunakan pedoman untuk da'i maupun kaum muslim pada umumnya yang akan melakukan dakwah. Keterbatasan penulis dalam tulisan ini, maka penelitian ini masih perlu ditindaklanjuti mencermati fenomena masyarakat yang lebih kompleks di era disrupsi ini.

\section{DAFTAR PUSTAKA}

Arifin, H.M.. (1997). Psikologi Dakwah Suatu Pengantar Studi. Jakarta: Bulan Bintang.

(1976). Psikologi dan Beberapa Aspek Kehidupan Rohaniah Manusia. Jakarta: Bulan Bintang.

Amin, Samsul Munir. (2010). Bimbingan dan Konseling Islam. Jakarta: Amzah. (2009). Ilmu Dakwah. Jakarta: Amzah.

(2008). Rekonstruksi Pemikiran Dakwah Islam. Jakarta: Amzah.

Ancok, Djamaluddin, dan Fuat Nashori Suroso. (1994). Psikologi Islam, Solusi Islam atas Problem-Problem Psikologi. Yogyakarta: Pustaka Pelajar.

Aziz, Moh. Ali. (2004). Ilmu Dakwah. Jakarta: PrenadaMedia. (2009). Ilmu Dakwah. edisi Revisi. Jakarta: Prenada Media.

Enjang dan Aliyudin. (2009). Dasar-dasar Ilmu Dakwah. Bandung: Widya Padjadjaran.

Faizah dan Lalu Muhsin Effendi. (2006). Psikologi Dakwah. Jakarta: Prenada Media.

Habib, M. Syafa'at. (1982). Buku Pedoman Dakwah. Jakarta: Widjaya.

Kartono, Kartini. (1996). Psikologi Sosial. bandung: Mandar Maju.

Mubarok, Achmad. (1997). Psikologi Dakwah. Pustaka Firdaus: Jakarta.

Sarwono, Sarlito Wirawan. (2000). Pengantar Umum Psikologi. Jakarta: Bulan Bintang. 
Musthofa. (2005). Dimensi-Dimensi Psikologis Kajian Ilmu Dakwah, dalam Jurnal Ilmu Dakwah. Vol II, No. 1 April 2005

Nawawi. (2007). Motivasi Terhadap Tingkah laku dalam Proses Dakwah, dalam Komunika, Jurnal Dakwah dan Komunikasi. Vol I, No. 2 JuliDesember 2007

Ramdhani, Neila. (2009). Pembentukan dan Perubahan Sikap. Yogyakarta: Fakultas Psikologi Universitas Gadjah Mada, at http://neila.staff. ugm.ac.id/wordpress/wpcontent/ uploads/2009/09/bab2a1-attitude. pdf. Diunduh pada 9 November 2017. 